\title{
Decrease of vitamin $D$ concentration in patients with HIV infection on a non nucleoside reverse transcriptase inhibitor-containing regimen
}

\author{
Anali Conesa-Botella ${ }^{1,2^{*}}$, Eric Florence ${ }^{1}$, Lutgarde Lynen ${ }^{1}$, Robert Colebunders ${ }^{1,2}$, Joris Menten ${ }^{3}$, \\ Rodrigo Moreno-Reyes ${ }^{4}$
}

\begin{abstract}
Background: Vitamin $D$ is an important determinant of bone health and also plays a major role in the regulation of the immune system. Interestingly, vitamin D status before the start of highly active antiretroviral therapy (HAART) has been recently associated with HIV disease progression and overall mortality in HIV-positive pregnant women. We prospectively studied vitamin D status in HIV individuals on HAART in Belgium.

We selected samples from HIV-positive adults starting HAART with a pre-HAART CD4 T-cell count $>100 \mathrm{cells} / \mathrm{mm}^{3}$ followed up for at least 12 months without a treatment change. We compared 25-hydroxyvitamin D plasma $[25-(\mathrm{OH}) \mathrm{D}]$ concentration in paired samples before and after 12 months of HAART. 25-(OH)D levels are presented using two different cut-offs: $<20 \mathrm{ng} / \mathrm{ml}$ and $<30 \mathrm{ng} / \mathrm{ml}$.

Results: Vitamin D deficiency was common before HAART, the frequency of plasma $25-(\mathrm{OH}) \mathrm{D}$ concentrations below $20 \mathrm{ng} / \mathrm{ml}$ and 30 below $\mathrm{ng} / \mathrm{ml}$ was $43.7 \%$ and $70.1 \%$ respectively. After 12 months on HAART, the frequency increased to $47.1 \%$ and $81.6 \%$.

HAART for 12 months was associated with a significant decrease of plasma 25-(OH)D concentration $(p=0.001)$. Decreasing plasma $25-(\mathrm{OH}) \mathrm{D}$ concentration on HAART was associated in the multivariate model with NNRTI-based regimen $(p=0.001)$ and lower body weight $(p=0.008)$. Plasma $25-(\mathrm{OH}) \mathrm{D}$ concentrations decreased significantly in both nevirapine and efavirenz-containing regimens but not in Pl-treated patients.

Conclusions: Vitamin D deficiency is frequent in HIV-positive individuals and NNRTI therapy further decreases 25-(OH)D concentrations. Consequently, vitamin D status need to be checked regularly in all HIV-infected patients and vitamin $\mathrm{D}$ supplementation should be given when needed.
\end{abstract}

\section{Background}

Vitamin D status is an important determinant of bone health. Vitamin D deficiency increases the risk of osteoporosis and fractures and in its most severe form causes rickets in children and osteomalacia in adults. In addition, a large number of studies indicate that vitamin D also plays an important role in insulin secretion, lipid metabolism, autoimmune disorders, cell proliferation, and cardiovascular diseases [1-8].

The main determinant of vitamin $\mathrm{D}$ status is the intraepidermal conversion of pre-vitamin D into vitamin D

\footnotetext{
* Correspondence: aconesa@itg.be

'Department of Clinical Sciences, Institute of Tropical Medicine, Antwerp, Belgium

Full list of author information is available at the end of the article
}

by ultra violet radiation. As a consequence, increased skin pigmentation and low sunlight exposure are risk factors for vitamin D deficiency [2]. Cholecalciferol is metabolized into 25-dihydroxyvitamin D [25- $(\mathrm{OH}) \mathrm{D}]$ in the liver and into its active form 1,25-dihydroxyvitamin $\mathrm{D}\left[1,25-(\mathrm{OH})_{2} \mathrm{D}\right]$ in the kidney and peripheral cells such as activated immune cells [8] by two successive hydroxylations by cytochromes P450 [9]. Both $1,25-(\mathrm{OH})_{2} \mathrm{D}$ and $25-(\mathrm{OH}) \mathrm{D}$ are catabolized by the cytochrome CYP24 [9]. In target cells such as immune cells, $1,25-(\mathrm{OH})_{2} \mathrm{D}$ is converted locally at the site of action [8]. Due to its longer half-life of 15 days, 25-(OH)D is considered the best marker of vitamin D status [8].

Although there is no agreement among international experts on the most appropriate cut-off value for

\section{Ciomed Central}


adequate vitamin D level, individuals with $25-(\mathrm{OH}) \mathrm{D}$ below $20 \mathrm{ng} / \mathrm{ml}$ are considered as deficient [2]. However, a value above $30 \mathrm{ng} / \mathrm{ml}$ has been suggested to be associated in the general population with better health outcomes such as higher bone mineral density, less falls and fractures as well as protection against cancer [10]. Lower vitamin D level has recently been associated with increased mortality in the general population [11] as well as with HIV disease progression and overall mortality in a cohort of Tanzanian pregnant women with HIV infection [12].

Paul et al. showed that vitamin D deficiency was more prevalent among HIV-positive patients treated with HAART when compared to HAART-naive patients and negative controls [13], however, Ramayo et al. showed opposite results [14]. In addition, HAART may impair vitamin D metabolism $[15,16]$ as shown by some in vitro studies. Cozzolino et al. [16] demonstrated the inhibition by protease inhibitors (PIs) of the 25-hydroxylase and the $1 \alpha$-hydroxylase involved in vitamin D metabolism. Ellfolk et al. [17] showed the inhibition of the 25-hydroxylase by efavirenz, a non-nucleoside reverse transcriptase inhibitor (NNRTI).

Vitamin D deficiency and bone disease in HAART patients $[14,18,19]$ have been associated with NNRTIs [20-22], as well as tenofovir [23,24], and PIs [19,24-26]. However, there is a lack of longitudinal studies on vitamin D variation during HAART; therefore we studied vitamin D status in a longitudinal cohort study of AIDS patients during the first year of HAART.

\section{Methods}

Subjects

Subjects were HIV-positive individuals belonging to the outpatient cohort of the Institute of Tropical Medicine (ITM) in Antwerp, Belgium. Antwerp is situated on the $51^{\text {st }}$ degree of latitude and receives 1000 hours of sun per year, half the exposure seen at the equator.

Using the ITM cohort electronic database we selected retrospectively patients fitting the following criteria: (a) HIV-positive adults starting HAART with CD4 T-cell counts $>100$ cells $/ \mathrm{mm}^{3}$; (b) followed up for at least 12 months; (c) without a treatment change in the first year of HAART. Individuals with a CD4 T-cell count below $100 \mathrm{cell} / \mathrm{mm}^{3}$ were excluded as they are often acutely unwell and may have other factors contributing to vitamin $\mathrm{D}$ deficiency.

Individuals were started either on a PI-based or on an NNRTI-based regimen. Patients on NNRTI were either on Nevirapine $(=20)$ or on Efavirenz $(n=23)$. Sixty-six percent $(n=29)$ of patients on PI were on a boosted regimen with Ritonavir. Twenty-seven individuals were taking Tenofovir; 18 in combination with NNRTIs and 8 with PIs. Patients taking corticosteroids, suffering from "severe renal disease" or "severe liver disease", or with an active granulomatous disease such as active tuberculosis, sarcoidosis and Crohn's disease were excluded. "Severe renal disease" was defined as urea and creatinine twofold above the normal reference values. "Severe liver disease" was defined as a patient having both elevated alanine aminotransferase and aspartate aminotransferase 5 times above the normal reference values.

All subjects had signed an informed consent allowing additional investigation for research purpose on the stored plasma samples left over of routine blood testing. The study was approved by the institutional review board of the ITM.

\section{Study design}

We selected individuals who had stored samples available at the start of HAART and 12 months later. We compared paired pre-HAART and post-HAART samples. The pre-HAART sample was drawn between the start of HAART and maximum 3 months before it. The 12 months sample was drawn minimum 3 months before and maximum 3 months after 12 months of HAART.

\section{Clinical data}

Clinical data were extracted and analyzed anonymously. We recorded the following variables: sex, skin color, season, age, weight, CD4 T-cell nadir and pre-HAART CD4 T-cell level, viral load, HIV disease stage, HAART regimen, total cholesterol, HDL-C, and LDL-C. No data on non prescribed vitamin $\mathrm{D}$ supplementation or sun exposure were routinely collected.

\section{Laboratory analysis}

Plasma samples were selected among stored samples obtained between 1997 and 2009. Plasma had been isolated by centrifugation of blood drawn on ethylenediaminetetraacetic acid (EDTA)-containing tubes and aliquots had been kept in a $-80^{\circ} \mathrm{C}$ freezer.

Total plasma $25-(\mathrm{OH}) \mathrm{D}$ was measured by radioimmunoassay (DiaSorin). The interassay coefficient of variation was $9-13 \%$. The quality control was performed by the vitamin D External Quality Assurance Survey (DEQAS). All samples were measured in duplicate. CD4 T-cell count was determined by standard flow cytometry (FACScalibur, Becton Dickinson). Viral load was measured with the Cobas Amplicor HIV-1 (Roche). Total cholesterol, HDL-C, and LDL level were determined by automated standard laboratory techniques.

\section{Vitamin D status}

Plasma 25- $(\mathrm{OH}) \mathrm{D}$ concentrations are presented using two different cut-offs, $<20 \mathrm{ng} / \mathrm{ml}(50 \mathrm{nmol} / \mathrm{l})$ and $<30 \mathrm{ng} / \mathrm{ml}(75 \mathrm{nmol} / \mathrm{l})$. 


\section{Statistical analysis}

All statistical analyses were performed with STATA and $\mathrm{R}$ software. Pre-HAART data was summarized using counts and percentages, means and standard deviations for normally distributed data, and median (interquartile range, IQR) for non-normal continuous variables. The difference between PI and NNRTI groups was assessed by Fisher's exact test for percentages, t-test for means and Mann-Whitney for medians. Normality was assessed using graphical methods and confirmed by D'agostino and Pearson omnibus normality test. Within-group or overall changes in vitamin D levels were assessed using a paired t-test. Logistic regression or linear regression methods were used to study the relation between the predictors and vitamin $\mathrm{D}$. A threshold of $\mathrm{p}<0,1$ was used for variable inclusion in the multivariate model, which was then simplified by backward elimination. $\mathrm{P}$-values presented in the text refer to the final statistical model obtained.

\section{Results}

\section{Subject characteristics}

Among the 194 patients fitting the inclusion criteria, plasma samples were available at both pre-HAART and 12 months for 89 patients. Two patients were excluded because of chronic liver disease. None of the patients had renal insufficiency, a known granulomatous disease or were treated with corticosteroids during the study period. A mean \pm SD of $381 \pm 39$ days was observed between both time points.

The pre-HAART population characteristics are summarized in Table 1. No significant differences at baseline were observed between patients on PI and NNRTIbased regimen. The "dark skin" group included 17 individuals from Central and Southern Africa; the "light skin" group included 68 Caucasians, one Moroccan and one Ecuadorian.

\section{Risk of vitamin D deficiency in HIV individuals before HAART}

Before HAART, $43.7 \%$ and $70.1 \%$ of the individuals had plasma 25- $(\mathrm{OH}) \mathrm{D}$ concentrations below $20 \mathrm{ng} / \mathrm{ml}$ and $30 \mathrm{ng} / \mathrm{ml}$, respectively. In multivariate analysis, darkskinned individuals had 8.9 and 11.2 times more risk than light-skinned individuals to present with plasma $25-(\mathrm{OH}) \mathrm{D}$ concentrations below $20 \mathrm{ng} / \mathrm{ml}$ and $30 \mathrm{ng} / \mathrm{ml}$ $(\mathrm{p}=0,001$ and 0,026$)$, respectively. In addition, the prevalence of plasma $25-(\mathrm{OH}) \mathrm{D}$ concentrations below 30 $\mathrm{ng} / \mathrm{ml}$ was higher in winter compared to summer $(\mathrm{p}=$ $0.001)$ and fall $(p=0.020)$. There was no significant effect of gender, age, weight or HIV disease stage, preHAART CD4 T-cell count or CD4 T-cell nadir, or viral load on vitamin D levels.
Table 1 Pre-HAART characteristics of the study population

\begin{tabular}{|c|c|c|c|c|}
\hline \multirow[t]{2}{*}{ Variables } & & \multirow{2}{*}{$\begin{array}{l}\text { NNRTI } \\
n=43\end{array}$} & \multirow{2}{*}{$\begin{array}{c}\text { PI } \\
N=44\end{array}$} & \multirow{2}{*}{$\begin{array}{r}p \\
\text { value }\end{array}$} \\
\hline & & & & \\
\hline 25-(OH)D (ng/ml) & mean $\pm S D$ & $26.6 \pm 13.5$ & $22.6 \pm 8.9$ & 0.101 \\
\hline Sex Male & n (\%) & 38 (88.4) & $34(77.3)$ & 0.256 \\
\hline Dark skin color & n (\%) & $7(16.3)$ & $10(22.7)$ & 0.590 \\
\hline \multicolumn{5}{|l|}{$\begin{array}{l}\text { Pre-HAART } \\
\text { sampling }\end{array}$} \\
\hline Winter & n (\%) & 15 (34.9) & 17 (38.6) & 0.657 \\
\hline Spring & n (\%) & $5(11.6)$ & $8(18.2)$ & \\
\hline Summer & n (\%) & $11(25.6)$ & $11(25.0)$ & \\
\hline Fall & n (\%) & $12(27.9)$ & $8(18.2)$ & \\
\hline Age (years) & $\begin{array}{l}\text { median } \\
(\mathrm{IQR})\end{array}$ & $\begin{array}{c}38.6 \\
(30.8 ; 44.8)\end{array}$ & $37(31.8 ; 44.6)$ & 0.929 \\
\hline Weight $(\mathrm{Kg})^{\alpha}$ & $\begin{array}{l}\text { median } \\
(\mathrm{IQR})\end{array}$ & $73(68 ; 85)$ & $70.5(65.3 ; 83.5)$ & 0.675 \\
\hline \multicolumn{5}{|l|}{ CD4 (cells $/ \mathrm{mm}^{3}$ ) } \\
\hline Nadir & $\begin{array}{l}\text { median } \\
(\mathrm{IQR})\end{array}$ & $\begin{array}{c}224 \\
(181 ; 292)\end{array}$ & $\begin{array}{c}247.5 \\
(182 ; 314.5)\end{array}$ & 0.61 \\
\hline pre-HAART & $\begin{array}{l}\text { median } \\
(\mathrm{IQR})\end{array}$ & $\begin{array}{c}254 \\
(183 ; 338)\end{array}$ & $299(241 ; 390.5)$ & 0.052 \\
\hline Viral Load $\left(\log _{10}\right)$ & $\begin{array}{l}\text { median } \\
(\mathrm{IQR})\end{array}$ & $\begin{array}{c}5.24 \\
(4.95 ; 5.53)\end{array}$ & $5.5(4.97 ; 5.86)$ & 0.168 \\
\hline \multicolumn{5}{|l|}{ HIV stage (CDC) } \\
\hline$A$ & n (\%) & $31(72.1)$ & $32(72.7)$ & 0.640 \\
\hline B & n (\%) & 8 (18.6) & $6(13.6)$ & \\
\hline C & n (\%) & $4(9.3)$ & 6 (13.6) & \\
\hline
\end{tabular}

PI: Protease inhibitors; NNRTI: non-nucleoside reverse transcriptase inhibitors; SD: Standard deviation; IQR: Interquartile range; ${ }^{\alpha} \mathrm{n}=85$

\section{Risk of vitamin D deficiency of HIV individuals during HAART}

After 12 months on HAART, $47.1 \%$ and $81.6 \%$ of individuals has plasma $25-(\mathrm{OH}) \mathrm{D}$ concentrations below 20 $\mathrm{ng} / \mathrm{ml}$ and $30 \mathrm{ng} / \mathrm{ml}$ respectively. Individuals with a darker skin color or being treated by a NNRTI-based regimen presented an increased risk of having plasma $25-(\mathrm{OH}) \mathrm{D}$ concentrations lower than $20 \mathrm{ng} / \mathrm{ml}$ (respectively 6 and 3 fold; $p=0,006$ and $p=0,020$ ). Individuals with a low body weight were 4.7 times more at a risk of having plasma 25- $(\mathrm{OH}) \mathrm{D}$ concentrations below $30 \mathrm{ng} / \mathrm{ml}(\mathrm{p}=0,026)$. There was no influence of sex, sampling season, pre-HAART CD4-T cell count and CD4 T-cell count nadir, viral load and HIV stage.

When analyzing paired pre-HAART and post-HAART samples from individuals on HAART for 12 months, we observed a significant decrease of plasma $25-(\mathrm{OH}) \mathrm{D}$ concentration in the studied population (Table 2). The decrease of $25-(\mathrm{OH}) \mathrm{D}$ was associated in the multivariate model to NNRTI-based regimen $(\mathrm{p}=0.001)$ and to a lower body weight $(\mathrm{p}=0.008)$. Moreover, plasma $25-(\mathrm{OH})$ D concentration decreased significantly after 12 months on NNRTI regimen (both on nevirapine and on efavirenz), 
Table 2 Determinants of 25(OH)D $(\mathrm{ng} / \mathrm{ml})$ decrease on HAART

\begin{tabular}{|c|c|c|c|}
\hline Variable & $\begin{array}{c}\text { 25(OH)D }(\mathrm{Cl}) \\
\text { pre-HAART }\end{array}$ & $\begin{array}{l}25(\mathrm{OH}) \mathrm{D}(\mathrm{Cl}) \\
\text { post-HAART }\end{array}$ & Adj $p$ \\
\hline Population & $24.6(22.1 ; 27.0)$ & $22.0(19.8 ; 24.1)$ & $0.001^{*}$ \\
\hline Sex & & & 0.668 \\
\hline M & $25.6(22.8 ; 28.4)$ & $22.8(20.4 ; 25.3)$ & \\
\hline F & $19.6(14.8 ; 24.4)$ & $17.8(14.0 ; 21.6)$ & \\
\hline Skin color & & & 0.195 \\
\hline Light & $26.7(24.0 ; 29.4)$ & $23.6(21.2 ; 26.0)$ & \\
\hline Dark & $15.8(11.9 ; 19.7)$ & $15.3(11.6 ; 19.0)$ & \\
\hline Pre-HAART sampling & & & 0.127 \\
\hline Winter & $21.9(18.1 ; 25.6)$ & $19.8(16.2 ; 23.5)$ & \\
\hline Spring & $22.1(16.5 ; 27.6)$ & $22.4(19.3 ; 25.5)$ & \\
\hline Summer & $29.8(24.2 ; 35.4)$ & $22.4(19.7 ; 29.0)$ & \\
\hline Fall & $24.8(19.1 ; 30.5)$ & $22.5(16.8 ; 28.2)$ & \\
\hline Age & & & 0.644 \\
\hline$<35$ years & $24.9(21.0 ; 28.7)$ & $22.2(18.6 ; 25.8)$ & \\
\hline $35-50$ years & $24.2(20.2 ; 28.2)$ & $21.2(17.8 ; 24.5)$ & \\
\hline$>50$ years & $24.8(20.0 ; 29.6)$ & $24.2(19.2 ; 29.2)$ & \\
\hline Weight (Kg) & & & 0.008 \\
\hline$\leq 70$ & $23.0(19.4 ; 26.6)$ & $18.5(16.2 ; 20.9)$ & \\
\hline$>70$ & $25.8(22.4 ; 29.2)$ & $24.8(21.4 ; 28.1)$ & \\
\hline CD4 $\left(\mathrm{CD} 4 / \mathrm{mm}^{3}\right)$ nadir & & & 0.160 \\
\hline$\leq 200$ & $25.4(21.0 ; 29.8)$ & $21.3(18.2 ; 24.5)$ & \\
\hline$>200$ & $24.1(21.1 ; 27.1)$ & $22.3(19.4 ; 25.3)$ & \\
\hline CD4 $\left(\mathrm{CD} 4 / \mathrm{mm}^{3}\right)$ pre-HAART & & & 0.174 \\
\hline$\leq 200$ & $25.9(20.5 ; 31.4)$ & $21.5(17.4 ; 25.6)$ & \\
\hline$>200$ & $24.1(21.3 ; 26.9)$ & $22.1(19.5 ; 24.8)$ & \\
\hline Viral Load $\left(\log _{10}\right)$ & & & 0.666 \\
\hline$>5$ & $25.7(22.9 ; 28.6)$ & $22.9(20.3 ; 25.6)$ & \\
\hline$\leq 5$ & $21.7(16.7 ; 26.6)$ & $19.6(15.8 ; 23.5)$ & \\
\hline HIV stage (CDC) & & & 0.760 \\
\hline A & $25.4(22.4 ; 28.4)$ & $22.7(20.0 ; 25.3)$ & \\
\hline B & $24.3(18.0 ; 30.5)$ & $21.0(15.7 ; 26.4)$ & \\
\hline$C$ & $19.8(13.0 ; 26.5)$ & $18.7(11.8 ; 25.6)$ & \\
\hline Therapy & & & 0.001 \\
\hline NNRTI & $26.6(22.5 ; 30.8)$ & $21.6(17.8 ; 25.5)$ & \\
\hline $\mathrm{Pl}$ & $22.6(19.9 ; 25.3)$ & $22.3(20.1 ; 24.6)$ & \\
\hline
\end{tabular}

$\mathrm{p}$ : p-value for comparison between groups (linear regression); adj p: $p$-value from final multivariate model (after backwards elimination); Cl: $95 \%$ confidence interval; ${ }^{*}$ non adjusted $\mathrm{p}$ value

but not in PI-treated patients (Figure 1). There was no association between the use of tenofovir and a decrease in vitamin $\mathrm{D}$ levels ( $\mathrm{p}=0.665$; data not shown).

\section{Changes in cholesterol HDL-C and LDL-C levels on HAART} After one year of HAART, we observed a significant increase in cholesterol concentration (from 168.5 to $202.5 \mathrm{mg} / \mathrm{dl} ; \mathrm{p}<0.001$; data not shown) and HDL-C levels (from 40.8 and $46.6 \mathrm{mg} / \mathrm{dl} ; \mathrm{p}=0.002$; data not shown). LDL-C level did not increase significantly

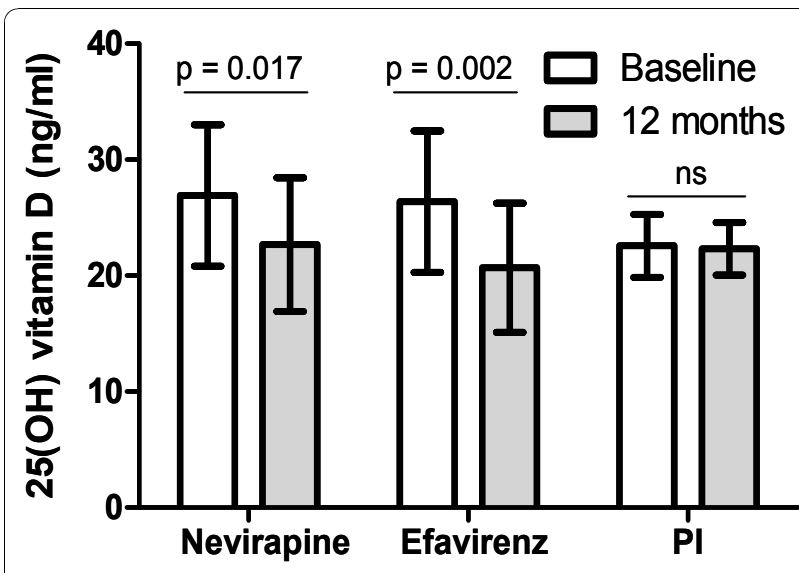

Figure 1 plasma 25(OH)D concentration pre-HAART and after 12 months in individuals on NNRTI-based regimen (Nevirapine and Efavirenz) and PI-based regimen. Pl: protease inhibitor.

$(\mathrm{p}=0.168$; data not shown $)$. There was no association between the increase of lipids and the pre-HAART vitamin D status or with the type of HAART.

\section{Discussion}

Our study shows a high prevalence of vitamin D deficiency in HIV-infected individuals as observed by others $[13,27,28]$. As reported in the general population $[2,29]$, vitamin D deficiency during summer and fall was lower than during winter.

We also showed that a NNRTI-based treatment was associated with a significant decrease of $25(\mathrm{OH}) \mathrm{D}$ plasma concentration after 12 months on HAART. Similarly to our findings, Van den Bout-van den Beukel [21] described a prevalence of vitamin D deficiency of $62 \%$ in dark-skinned individuals in a cross-sectional study of HIV-positive individuals. In their study, patients on an NNRTI-based therapy had lower vitamin D levels than those on a PI-based therapy.

Decreased bone mineral density is often described in cross sectional studies in patients on tenofovir (NRTI) [23,30] or PIs [19,24-26]. However, we and others found an association between NNRTI-based regimen and vitamin D levels [21,22]. The lack of concordant findings on the effect of HAART on bone mineral density and vitamin $\mathrm{D}$ might result from the direct action of antiretroviral drugs on osteoclasts and osteoblasts $[26,31,32]$. The effect of NRTI drugs on vitamin D metabolism has never been studied but interactions are unlikely as NRTIs are not metabolized by cytochromes [33]. In contrast, PI and NNRTI drugs have been shown to interfere with cytochromes involved in the vitamin D metabolism (e.g. NNRTI induce CYP3A4; PIs inhibit CYP3A4) $[9,16,17,33-35]$. The role of each antiretroviral drug particularly from the NNRTI family on vitamin D metabolism should be evaluated further to better understand 
the action of HAART on enzymes involved in vitamin D metabolism.

Our data show that patients with a body weight $\leq$ $70 \mathrm{~kg}$ had a higher risk of plasma $25-(\mathrm{OH}) \mathrm{D}$ concentration below $30 \mathrm{ng} / \mathrm{ml}$ after one year on HAART. A similar association has been reported, in HIV-infected individuals with BMI and vitamin D status [36]. These results are different from those of non HIV-infected patients, where obesity is associated with lower plasma $25-(\mathrm{OH}) \mathrm{D}$ concentrations [37] and a slower increase of vitamin $\mathrm{D}$ concentration in response to UVB irradiation. In non-HIV infected individuals, this has been explained by an altered release of vitamin D from the skin into the circulation, and the decreased bioavailability of vitamin D by deposition in body fat compartment [37].

This study has several limitations. The small sample size precluded determination of whether the decrease of plasma 25- $(\mathrm{OH}) \mathrm{D}$ concentration was associated with the use of a certain HAART combination. In addition, the retrospective design and the lack of detailed information about UV radiation exposure and over the counter multivitamin supplementation limited our study.

Our results suggest that HIV patients and particularly those treated with HAART represent a population with higher risk of vitamin D deficiency. Beyond bone health, vitamin $\mathrm{D}$ deficiency is associated with many chronic diseases such as cancer, cardiovascular disease, diabetes and immunological diseases including HIV as well as chronic pain in HIV-infected individuals [10,11,38-41].

Vitamin D supplementation to maintain an optimal plasma $25-(\mathrm{OH}) \mathrm{D}$ concentration above $30 \mathrm{ng} / \mathrm{ml}$ is an inexpensive and a safe measure as vitamin $\mathrm{D}$ toxicity is only observed at plasma $25-(\mathrm{OH}) \mathrm{D}$ concentration higher than $150 \mathrm{ng} / \mathrm{ml}$ [2]. Therefore, clinicians taking care of HIV patients should be aware of the risk of vitamin D deficiency associated with HIV and HAART and the benefits of its supplementation.

\section{Conclusions}

In conclusion, our findings suggest that vitamin D deficiency is highly prevalent in HIV individuals and that NNRTI therapy further decreases 25-(OH)D concentrations. Consequently, vitamin $\mathrm{D}$ status need to be checked regularly in all HIV-infected patients and vitamin D supplementation should be given when needed.

\footnotetext{
Acknowledgements

We would like to thank Hoste J. and Van Den Heuvel A. for their help in data and sample collection. Research funded by a Ph.D. grant (ConesaBotella A.) from the Flemish Interuniversity Council (VLIR).
}

\section{Author details}

${ }^{1}$ Department of Clinical Sciences, Institute of Tropical Medicine, Antwerp, Belgium. ${ }^{2}$ Department of Epidemiology and Social Medicine, University of Antwerp, Belgium. ${ }^{3}$ Clinical Trials Unit, Institute of Tropical Medicine,
Antwerp, Belgium. ${ }^{4}$ Department of Nuclear Medicine, Erasmus Hospital, Free University of Brussels, Belgium.

\section{Authors' contributions}

CBA extracted the data, performed the data analysis, and wrote the paper. $F E, L L, M R R$, and CR. collaborated in conceiving the study and in the writing and reviewing of the article MJ collaborated to the statistical analysis. All authors read and approved the final manuscript.

\section{Competing interests}

The authors declare that they have no competing interests.

Received: 18 October 2010 Accepted: 23 November 2010 Published: 23 November 2010

\section{References}

1. Chiu KC, Chu A, Go VL, Saad MF: Hypovitaminosis D is associated with insulin resistance and beta cell dysfunction. Am J Clin Nutr 2004, 79:820-825

2. Holick MF: Vitamin D deficiency. N Engl J Med 2007, 357:266-281.

3. Hypponen E, Laara E, Reunanen A, Jarvelin MR, Virtanen SM: Intake of vitamin D and risk of type 1 diabetes: a birth-cohort study. Lancet 2001, 358:1500-1503.

4. Liu PT, Stenger S, Li H, Wenzel L, Tan BH, Krutzik SR, Ochoa MT, Schauber J, Wu K, Meinken C, Kamen DL, Wagner M, Bals R, Steinmeyer A, Zugel U, Gallo RL, Eisenberg D, Hewison M, Hollis BW, Adams JS, Bloom BR, Modlin RL: Toll-like receptor triggering of a vitamin D-mediated human antimicrobial response. Science 2006, 311:1770-1773.

5. Martins D, Wolf M, Pan D, Zadshir A, Tareen N, Thadhani R, Felsenfeld A, Levine B, Mehrotra R, Norris K: Prevalence of cardiovascular risk factors and the serum levels of 25-hydroxyvitamin $D$ in the United States: data from the Third National Health and Nutrition Examination Survey. Arch Intern Med 2007, 167:1159-1165.

6. Mathieu C, Gysemans C, Giulietti A, Bouillon R: Vitamin D and diabetes. Diabetologia 2005, 48:1247-1257.

7. Scragg R, Jackson R, Holdaway IM, Lim T, Beaglehole R: Myocardial infarction is inversely associated with plasma 25 -hydroxyvitamin D3 levels: a community-based study. Int J Epidemiol 1990, 19:559-563.

8. Baeke F, Takiishi T, Korf H, Gysemans C, Mathieu C: Vitamin D: modulator of the immune system. Curr Opin Pharmacol 2010, 10(4):482-96.

9. Prosser $D E$, Jones $G$ : Enzymes involved in the activation and inactivation of vitamin D. Trends Biochem Sci 2004, 29:664-673.

10. Bischoff-Ferrari HA, Giovannucci E, Willett WC, Dietrich T, Dawson-Hughes B: Estimation of optimal serum concentrations of 25-hydroxyvitamin D for multiple health outcomes. Am J Clin Nutr 2006, 84:18-28.

11. Melamed ML, Michos ED, Post W, Astor B: 25-hydroxyvitamin D levels and the risk of mortality in the general population. Arch Intern Med 2008, 168:1629-1637.

12. Mehta S, Giovannucci E, Mugusi FM, Spiegelman D, Aboud S, Hertzmark E, Msamanga Gl, Hunter D, Fawzi WW: Vitamin D status of HIV-infected women and its association with HIV disease progression, anemia, and mortality. PLoS One 2010, 5:e8770.

13. Paul TV, Asha HS, Thomas N, Seshadri MS, Rupali P, Abraham OC Pulimood SA, Jose A: Hypovitaminosis D and Bone Mineral Density in HIV infected Indian Men with or without antiretroviral therapy. Endocr Pract 2010, 16(4):547-53.

14. Ramayo E, Gonzalez-Moreno MP, Macias J, Cruz-Ruiz M, Mira JA, VillarRueda AM, Garcia-Garcia JA, Gomez-Mateos JM, Lozano F, Pineda JA: Relationship between osteopenia, free testosterone, and vitamin $D$ metabolite levels in HIV-infected patients with and without highly active antiretroviral therapy. AIDS Res Hum Retroviruses 2005, 21:915-921.

15. Fabbriciani G, De Socio GV: Efavirenz and bone health. AIDS 2009, 23:1181.

16. Cozzolino M, Vidal M, Arcidiacono MV, Tebas P, Yarasheski KE, Dusso AS: HIV-protease inhibitors impair vitamin D bioactivation to 1,25dihydroxyvitamin D. AIDS 2003, 17:513-520.

17. Ellfolk M, Norlin M, Gyllensten K, Wikvall K: Regulation of human vitamin $D$ (3) 25 -hydroxylases in dermal fibroblasts and prostate cancer LNCaP cells. Mol Pharmacol 2009, 75:1392-1399.

18. Aukrust P, Haug CJ, Ueland T, Lien E, Muller F, Espevik T, Bollerslev J, Froland SS: Decreased bone formative and enhanced resorptive markers in human immunodeficiency virus infection: indication of normalization 
of the bone-remodeling process during highly active antiretroviral therapy. J Clin Endocrinol Metab 1999, 84:145-150.

19. Madeddu G, Spanu A, Solinas P, Calia GM, Lovigu C, Chessa F, Mannazzu M, Falchi A, Mura MS, Madeddu G: Bone mass loss and vitamin D metabolism impairment in HIV patients receiving highly active antiretroviral therapy. Q J Nucl Med Mol Imaging 2004, 48:39-48.

20. Gyllensten K, Josephson F, Lidman K, Saaf M: Severe vitamin D deficiency diagnosed after introduction of antiretroviral therapy including efavirenz in a patient living at latitude 59 degrees N. AIDS 2006, 20:1906-1907.

21. Van Den Bout Van Den Beukel CJ, Fievez L, Michels M, Sweep FC, Hermus AR, Bosch ME, Burger DM, Bravenboer B, Koopmans PP, Van DV: Vitamin $D$ deficiency among HIV type 1-infected individuals in the Netherlands: effects of antiretroviral therapy. AIDS Res Hum Retroviruses 2008, 24:1375-1382.

22. Mueller NJ, Fux CA, Ledergerber B, Elzi L, Schmid P, Dang T, Magenta $L$, Calmy A, Vergopoulos A, Bischoff-Ferrari HA: High prevalence of severe vitamin $D$ deficiency in combined antiretroviral therapy-naive and successfully treated Swiss HIV patients. AIDS 2010, 24:1127-1134.

23. Childs K, Kadish C, Branch-Elliman W, Fishman S, Mullen M, Branch A: Vitamin $D$ and calcium supplements reverse the secondary hyperparathyroidism that commonly occurs in HIV patients on TDF containing HAART. 15th Annual Conference of the British HIV Association, Liverpool, UK; HIV Med 2009, 10(Suppl. 1), 40 Abstract P89.

24. Rivas P, Gorgolas M, Garcia-Delgado R, az-Curiel M, Goyenechea A, Fernandez-Guerrero ML: Evolution of bone mineral density in AIDS patients on treatment with zidovudine/lamivudine plus abacavir or lopinavir/ritonavir. HIV Med 2008, 9:89-95.

25. Duvivier C, Kolta S, Assoumou L, Ghosn J, Rozenberg S, Murphy RL, Katlama C, Costagliola D: Greater decrease in bone mineral density with protease inhibitor regimens compared with nonnucleoside reverse transcriptase inhibitor regimens in HIV-1 infected naive patients. AIDS 2009, 27:817-824.

26. Brown TT, Qaqish RB: Antiretroviral therapy and the prevalence of osteopenia and osteoporosis: a meta-analytic review. AIDS 2006, 20:2165-2174.

27. Rodriguez M, Daniels B, Gunawardene S, Robbins GK: High Frequency of Vitamin D Deficiency in Ambulatory HIV-Positive Patients. AIDS Res Hum Retroviruses 2008, 25(1):9-14.

28. Rosenvinge M, Gedela K, Copas A, Wilkinson A, Sheehy C, Bano G, Hay P, Pakianathan M, Sadiq S: Tenofovir-Linked hyperparathyroidism Is Independently Associated With Presence of Vitamin D Deficiency. Acquir Immune Defic Syndr 2010, 54(5):496-9.

29. Moreno-Reyes R, Carpentier YA, Boelaert M, El MK, Dufourny G, Bazelmans C, Leveque A, Gervy C, Goldman S: Vitamin D deficiency and hyperparathyroidism in relation to ethnicity: a cross-sectional survey in healthy adults. Eur J Nutr 2009, 48(1):31-7.

30. Gallant JE, Staszewski S, Pozniak AL, DeJesus E, Suleiman JM, Miller MD, Coakley DF, Lu B, Toole JJ, Cheng AK: Efficacy and safety of tenofovir DF vs stavudine in combination therapy in antiretroviral-naive patients: a 3year randomized trial. JAMA 2004, 292:191-201.

31. Amorosa V, Tebas P: Bone disease and HIV infection. Clin Infect Dis 2006, 42:108-114.

32. Thomas J, Doherty SM: HIV infection-a risk factor for osteoporosis. $J$ Acquir Immune Defic Syndr 2003, 33:281-291.

33. Zapor MJ, Cozza KL, Wynn GH, Wortmann GW, Armstrong SC: Antiretrovirals, Part II: focus on non-protease inhibitor antiretrovirals (NRTIs, NNRTIs, and fusion inhibitors). Psychosomatics 2004, 45(6):524-35.

34. Hariparsad N, Nallani SC, Sane RS, Buckley DJ, Buckley AR, Desai PB: Induction of CYP3A4 by efavirenz in primary human hepatocytes: comparison with rifampin and phenobarbital. J Clin Pharmacol 2004, 44:1273-1281.

35. Wynn GH, Zapor MJ, Smith BH, Wortmann G, Oesterheld JR, Armstrong SC, Cozza KL: Antiretrovirals, part 1: overview, history, and focus on protease inhibitors. Psychosomatics 2004, 45(3):262-70.

36. Borderi M, Vescini F, Cozzi-Lepri A, Di Caro A, Shlacht I, Cassola G Pellizzer G, Vecchiet J, Re M, d'Arminio Monforte A: Prevalence of Hypovitaminosis D among HIV+ Patients Enrolled in a Large italian Cohort. 17th Conference on Retroviruses and Opportunistic Infections San Fransisco, California; 2010, Poster 751.

37. Wortsman J, Matsuoka LY, Chen TC, Lu Z, Holick MF: Decreased bioavailability of vitamin D in obesity. Am J Clin Nutr 2000, 72:690-693.
38. Bischoff-Ferrari H: Health effects of vitamin D. Dermatol Ther 2010, 23:23-30.

39. Glare PA: Pain in patients with HIV infection: issues for the new millennium. Eur J Pain 2001, 5(Suppl A):43-48

40. Prakash S, Shah ND: Chronic tension-type headache with vitamin D deficiency: casual or causal association? Headache 2009, 49:1214-1222.

41. Straube S, Andrew MR, Derry S, McQuay HJ: Vitamin D and chronic pain. Pain 2009, 141:10-13.

doi:10.1186/1742-6405-7-40

Cite this article as: Conesa-Botella et al:: Decrease of vitamin D concentration in patients with HIV infection on a non nucleoside reverse transcriptase inhibitor-containing regimen. AIDS Research and Therapy 2010 7:40.

\section{Submit your next manuscript to BioMed Central and take full advantage of:}

- Convenient online submission

- Thorough peer review

- No space constraints or color figure charges

- Immediate publication on acceptance

- Inclusion in PubMed, CAS, Scopus and Google Scholar

- Research which is freely available for redistribution 